\title{
KORUPSI KEBIJAKAN OLEH PEJABAT PUBLIK (SUATU ANALISIS PERSPEKTIF KRIMINOLOGI)
}

\author{
Made Sugi Hartono \\ Mahasiswa Doktor Fakultas Hukum Universitas Gadjah Mada \\ Dosen Hukum Pidana Fakultas Hukum \\ Universitas Udayana Denpasar \\ Email : unusangobleg@gmail.com
}

\begin{abstract}
ABSTRAK
Kajian ini bertujuan untuk mengurai dasar teoritik terhadap klaim korupsi kebijakan publik sebagai suatu fenomena yang berkembang di masyarakat. Dengan menggunakan metode yuridis-normatif berbasis data sekunder yang dianalisis melalui pendekatan kasus, konseptual serta pendekatan sejarah, kajian ini diharapkan mampu memberikan gambaran holistik tentang korupsi kebijakan dengan kriminologi sebagai pisau analisisnya.

Korupsi kebijakan oleh pejabat publik lahir menjadi korupsi jenis baru yang banyak menyita perhatian publik. Korupsi jenis ini menjadi suatu fenomena yang berkembang pada masyarakat Indonesia. Kasus-kasus yang melibatkan Siti Fadilah Supari, Hadi Poenomo dan Budi Mulya adalah beberapa kasus yang menjadi bukti verifikatif bahwa fenomena korupsi kebijakan nyata dalam praktek kenegaraan di Indonesia. Korupsi kebijakan dalam perspektif kriminologi termasuk kualifikasi white collar crime dengan turunannya yaitu occupational crime dan discretionary crime. Korupsi kebijakan lahir karena adanya jabatan tertentu dengan wewenang yang legitimate berdasarkan hukum akan tetapi terdapat kepentingan pribadi di tengah kepentingan masyarakat sebagai nilai jahat untuk mencuri uang negara. Pada titik ini terlihat bagaimana hubungan kekuasan dengan praktek korupsi yang memiliki kecenderungan semakin besar kekuasaan maka potensi korupsi akan semakit tinggi.
\end{abstract}

\section{Kata Kunci: Korupsi, Kebijakan Publik, Kriminologi.}

\section{ABSTRACT}

This study aims to unravel the theoretical basis to the claims of corruption of public policy as a growing phenomenon in society. By using the juridical-normative method based on secondary data analyzed through case approach, conceptual and historical approach, this study is expected to provide a holistic picture of corruption policies criminology as a knife analysis.

Corruption policy by public officials was born into a new kind of corruption that much public attention. Corruption of this kind become a growing phenomenon in Indonesian society. Cases involving Siti Fadilah Supari, Hadi Budi Mulya Poenomo and is some cases the proof verification that the phenomenon of corruption is evident in the practice of state policy in Indonesia. Corruption policies in the perspective of criminology, including the qualification white collar crime with crime and its derivatives are discretionary occupational crime. Corruption birth policy for their particular position with the legitimate authority based on the law but there are vested interests in the interests of society as a malicious value for stealing state 
money. At this point seen how the relationship with the corrupt powers that have the greater tendency of power, the potential for corruption will be higher.

\section{Keywords: Corruption, Public Policy, Criminology}

\section{Pendahuluan}

Korupsi di Indonesia telah merambah hampir semua sektor kehidupan berbangsa dan bernegara. Hampir dapat dipastikan, tidak ada satu ranahpun yang tidak tersentuh korupsi, baik itu ranah politik, ekonomi, sosial, budaya bahkan agama. Dari segi efeknya, kerusakan yang ditimbulkan korupsi sedemikian nyata. Mulai dari kebocoran anggaran negara dalam jumlah besar sampai kepada kemiskinan yang menjerat sebagian besar warga negara. Hal demikian merupakan dampak langsung maupun tidak langsung dari korupsi.

Korupsi merupakan subkultur yang tumbuh subur dalam kehidupan masyarakat Indonesia. Begitu subur praktek korupsi yang terjadi, menjadikan Indonesia sebagai salah satu negara dengan tingkat korupsi tinggi. Transparansi International pada survei tahun 2014 mencatat Indonesia menduduki ranking ke-107 dengan skor 34 dari 175 negara yang diukur. Indonesia berada di bawah Filipina (ranking 85, skor 38) dan Malaysia (ranking 50, skor 52) (Transparancy International The Global Coalition Against Corruption).

Menurut Indonesian Corruption Watch (ICW) tren korupsi di Indonesia makin hari makin menghawatirkan. Pada tahun 2011, kasus korupsi yang berhasil diproses oleh KPK dan Kejaksaan mencapai 436 kasus dan melibatkan 1.053 tersangka dan perkiraan kerugian negara yang ditimbulkan mencapai Rp. 2,169 Triliun. Selanjutnya, pada enam bulan pertama tahun 2012, KPK dan Kejaksaan berhasil menangkap 597 tersangka korupsi dan menyidik 285 kasus dan kerugian negara yang dialami mencapai 1,22 Triliun (Laode M. Syarif dan Didik E.).

Tingginya angka korupsi di Indonesia dapat juga terlihat dari statistik penanganan perkara yang dilakukan oleh Komisi Pemberantasan Korupsi (KPK). Rekapitulasi Penindakan Pidana Korupsi KPK per 31 Maret 2015 dengan periode tahun 2004 sampai tahun 2015 mencatat secara rinci sebagai berikut: penyelidikan sebanyak 690 kasus, penyidikan sebanyak 421 kasus, penuntutan sebanyak 237 kasus, inkracht sebanyak 291 kasus dan eksekusi sebanyak 304 kasus (ACCH). Sementara, menurut tabulasi data penanganan korupsi berdasarkan jenis perkara tahun 2004 sampai 2014 menunjukkan angka yaitu: pengadaan barang/jasa sebanyak 126 kasus, perijinan sebanyak 17 kasus, penyuapan 182 kasus, pungutan sebanyak 18 kasus, penyalahgunaan anggaran sebanyak 42 kasus, tindak pidana pencucian uang sebanyak 13 kasus, merintangi proses KPK sebanyak 4 kasus. Total kasus secara keseluruhan yaitu sebanyak 402 kasus (http://acch.kpk.go.id).

Data statistik yang dirilis oleh KPK merupakan indikator bahwa tingkat korupsi di Indonesia masih sangat tinggi. Praktek korupsi terjadi di tiga sumber kekuasaan baik eksekutif, legislatif maupun yudikatif. Prilaku korup seolah menjadi tren 
pejabat negara dewasa ini. Dengan kewenangan yang dimiliki, seorang pejabat mengambil suatu kebijakan yang memang mengandung unsur menguntungkan diri sendiri.

Jenis korupsi yang banyak dibahas akhir-akhir ini adalah korupsi yang terjadi pada kebijakan publik. Kebijakan publik, sebelumnya merupakan alat untuk melakukan korupsi. Sementara itu, kebijakan publik kini berubah menjadi jenis korupsi tersendiri dengan istilah korupsi kebijakan. Istilah korupsi kebijakan dicetuskan oleh Sudirman Said sebagai Ketua Badan Pelaksana Masyarakat Transpanransi dalam lokakarya nasional mengenai strategi pemberantasan korupsi. Menurut Sudirman

(http://www.hukumonline.com)

faktor yang mendukung terjadinya korupsi kebijakan adalah terjadinya deregulasi pada awal 1980-an yang memberi peran lebih besar kepada swasta. Sumber daya sebagian besar dikuasai oleh swasta, sehingga semakin banyak aktivitas utama diserahkan kepada swasta. Hal ini mengakibatkan peran pemerintah pada wilayah distribusi semakin sedikit. Oleh karena peran pemerintah hanya sebagai fasilitator dan regulator, maka kesempatan untuk melakukan korupsi menjadi sempit. Dengan demikian, konsentrasi korupsi mengarah pada wilayah pembentukan kebijakankebijakan publik. Pada titik inilah terjadi kerentanan adanya korupsi kebijakan.

Kasus berkaitan dengan korupsi pada kebijakan publik adalah kasus mantan Bupati Subang Eep Hidayat. Eep Hidayat menjadi terpidana dalam kasus korupsi biaya pungut pajak bumi dan bangunan Subang.
Mahkamah Agung dalam putusanya menyatakan Eep Hidayat bersalah dan menjatuhkan pidana lima tahun penjara, denda Rp. 200 juta subsider tiga bulan penjara serta uang pengganti yang diserahkan kepada negara sebesar Rp. 2, 584 miliar. Putusan Mahkamah Agung ini membatalkan putusan Pengadilan Tipikor Bandung yang menjatuhkan putusan bebas kepada Eep Hidayat (http://ditjenmiltun).

Korupsi pada kebijakan publik memunculkan dua pandangan yang berbeda diantara tokoh politik, penegak hukum, akademisi, praktisi dan lain sebagainya. Satu pihak menyatakan bahwa kebijakan pejabat publik tidak dapat diproses secara pidana sebab mengambil kebijakan merupakan wewenang, tugas dan tanggungjawab yang harus dilakukan oleh pejabat publik. Di lain pihak, khususnya dari perspektif hukum pidana memandang bahwa kebijakan dapat diproses secara pidana apabila kebijakan yang diambil pejabat publik memang diniatkan oleh yang bersangkutan untuk berbuat korup. Romli Atmasasmita (2013) menyatakan bahwa masih terdapat perbedaan pendapat para ahli hukum Indonesia tentang tanggungjawab hukum penyelenggara negara, apakah kebijakan pemerintah khusus penyelenggara negara termasuk ranah hukum administrasi negara atau ranah hukum pidana. Perdebatan ini sering terjadi dalam kasus korupsi terkait perpajakan dan pengadan barang dan jasa.

Hal yang menarik terkait korupsi kebijakan adalah apa yang dilakukan oleh pemerintah dewasa ini. Presiden Joko Widodo mengeluarkan Surat Edaran tentang kebijakan dan kesalahan 
admisnistrasi yang tidak bisa dipidana yang nantinya akan menjadi rujukan bagi kepada daerah agar tidak takut lagi merealisasikan program yang telah direncanakan (Bali Post, Minggu 6 September 2015). Selain itu, Presiden Joko Widodo juga akan menerbitkan dua peraturan pemerintah sebagai turunan dari Undang-Undang Nomor 30 Tahun 2014 tentang Administrasi Pemerintahan. Kedua Peraturan Pemerintah tersebut yaitu Peraturan Pemerintah Sanksi Administratif dan Peraturan Pemerintah Tata Cara Pengembalian Kerugian Negara (Kompas, Senin 14 September 2015). Tujuan dikeluarkannya SE dan kedua PP tersebut adalah agar pejabat tidak ragu-ragu dan takut dalam menetapkan kebijakan publik sehingga perekonomian dapat berjalan sebagaimana mestinya. Hal ini dilakukan karena kurang maksimalnya pencairan anggaran daerah oleh sejumlah daerah mengakibatkan banyak daerah tidak mampu merealisasikan program dan kegiatan yang telah direncanakan melalui Rencana Pembangunan Jangka Menengah Daerah (RPJMD), Rencana Kerja Pembangunan Daerah (RKPD) dan Rencana Strategis Satuan Kerja Pemerintah Daerah (Renstra SKPD). Kondisi ini juga dikatakan sebagai salah satu pemicu semakin memburuknya nilai tukar rupiah terhadap dollar AS sebab anggaran daerah tidak mampu memberikan stimulus fiskal (Kompas, Selasa 22 September 2015.). Sekitar Rp. 270 triliun dana APBD masih mengendap di Bank Pembangunan daerah hingga semester I tahun 2015. Hal ini karena adanya keraguan dan ketakutan dari kepala daerah melaksanakan anggaran pembangunan dan belanja daerah (Bali Post, Rabu 26 Agustus 2015).

Persoalan ini menjadi menarik untuk dikaji. Di satu sisi, pejabat negara memiliki tugas dan kewajiban yang melekat padanya untuk menyelenggarakan pemerintahan sebagai pelayanan publik yang pada giliranya adalah untuk kesejahteraan rakyat. Di sisi lain, terjadi penyalahgunaan kekuasaan oleh pejabat negara untuk kepentingan sendiri yang tentunya merugikan keuangan negara. Pada titik ini terlihat kebijakan sebagai alat untuk melakukan korupsi atau kebijakan tersebut merupakan korupsi jenis baru yang disebut dengan korupsi kebijakan. Kebijakan dikeluarkan untuk menyamarkan niat jahat dari pelaku sehingga dapat merampok uang nagara.

Pemikiran kritis yang berkaiatan dengan masalah korupsi kebijakan perlu dikembangkan. Korupsi kebijakan sebagai suatu kejahatan dapat dianalisis dengan menggunakan pisau analisis kriminologi. Kriminologi sebagai pisau analisis mengandung arti bahwa kriminologi digunakan sebagai alat untuk membedah dan menganalisis fenomena kejahatan sehigga dihasilkan suatu uraian jelas mengenai faktor-faktor yang mempengaruhi kejahatan tersebut. Bonger (1982) mendefinisikan kriminologi adalah ilmu pengetahuan yang bertujuan menyelidiki gejala kejahatan seluas-luasnya (kriminologi teoritis atau murni). Kriminologi teoritis adalah ilmu pengetahuan yang berdasarkan pengalaman yang seperti ilmu pengetahuan lainnya yang sejenis, memperhatikan gejala-gejala dan mencoba menyelidiki sebab-sebab 
dari gejala tersebut dengan cara-cara apa adanya. Sementara itu, menurut Sutherland dan Cressey (Stephan Hurwitz, 1986) Kriminologi adalah keseluruhan ilmu-ilmu pengetahuan yang berhubungan dengan kejahatan sebagai suatu gejala masyarakat.

Mengurai korupsi dalam bentuk kebijakan pejabat publik dalam perspektif kriminologi berarti, memberikan pemaparan mengenai korupsi dalam bentuk kebijakan pejabat publik sebagai suatu gejala masyarakat. Lebih lanjut, uraian mengenai sebab apa yang mempengaruhi sampai pada kondisi bagaimana korupsi tersebut dilakukan. Termasuk di dalamnya adalah siapa serta bagaimana latar belakang pelaku korupsi tersebut. Dengan demikian akan diperoleh uraian mengenai fenomena korupsi yang diwujudkan dalam bentuk kebijakan pejabat publik, bagaimana hubungan prilaku korup dengan posisi yang dimiliki pejabat publik tersebut. Kriminologi bekerja pada ranah bagaimana kejahatan tersebut muncul, menganalisis sebab dari kejahatan tersebut. Ini adalah bentuk kontribusi ilmu pengetahuan dalam menyelesaikan persoalan manusia yang pada gilirannya adalah untuk manusia itu sendiri.

\section{Rumusan Masalah}

Berdasarkan pada uraian sebelumnya, penulis merumuskan masalah sebagai berikut: Bagaimanakah fenomena korupsi kebijakan oleh pejabat negara dalam perspektif kriminologi?

\section{Pembahasan \\ Perihal Korupsi Kebijakan Pejabat Negara}

Korupsi kebijakan merupakan fenomena yang banyak disoroti oleh publik Indonesia beberapa tahun terakhir ini. Alasannya adalah, adakalanya fenomena ini memunculkan perdebatan dikalangan para pakar apakah kebijakan pejabat publik yang bermasalah diproses melalui mekanisme hukum administrasi negara sebagai maladministrasi ataukah melalui hukum pidana sebagai tindak pidana korupsi. Selanjutnya, dalam perspektif hukum pidana, korupsi kebijakan merupakan wujud korupsi jenis baru dengan modus operandi canggih melibatkan orang-orang berkuasa sehingga sering kali penegakan hukum korupsi jenis ini mengalami kendala yang serius. Terdapat beberapa contoh kasus mengenai korupsi kebijakan pada variasi level peradilan yang berbeda satu dengan yang lainnya.

Kasus korupsi kebijakan yang pertama adalah kasus yang melibatkan mantan Menteri Kesehatan Siti Fadilah Supari. Siti Fadilah ditetapkan sebagai tersangka atas kasus dugaan penyalahgunaan wewenang tindak pidana korupsi terkait pengadaan barang dengan mekanisme penunjukan langsung pembuatan vaksin flu burung yang mengakibatkan negara mengalami kerugian sekitar Rp. 6 miliar. Siti Fadilah pada kasus ini menyetujui penunjukan langsung pengadaan alat kesehatan dan perbekalan rumah sakit untuk mengatasi wabah flu burung. Siti Fadilah harus melakukan diskresi karena keterbatasan waktu (SBD). Kasus lain yaitu kasus yang melibatkan mantan Ketua Badan Pemeriksa Kuangan (BPK) Hadi Poernomo dan Mantan Deputi Gubernur Bank Indondesia Budi 
Mulya. Terdapat kemiripan pada kasus keduanya yaitu mengenai pembuatan kebijakan. Hadi diduga menyalahgunakan kewenangannya saat menjabat Dierjen Pajak (20022004) dalam mengambil keputusan atas permohonan keberatan pajak yang diajukan oleh BCA (http://nasional.news.viva.co.id).

Pembahasan mengenai korupsi kebijakan dimulai dengan memahami arti kebijakan publik yang dilanjutkan dengan memahami korupsi dalam kaitannya dengan kekuasaan. Pembahasan hubungan antara korupsi kebijakan dengan kekuasaan menjadi penting sebab kebijakan lahir dengan adanya kekuasaan yang lagitimate berdasarkan hukum atau kewenangan dari pelaku korupsi tersebut. Kewenangan inilah yang dimanfaatkan oleh para pelaku untuk mewujudkan niat jahatnya untuk bertindak korup.

Istilah kebijakan publik merupakan terjemahan dari istilah Inggris "Public Policy". Terkait dengan kata "Policy", terdapat dua terjemahan yang masih belum disepakati secara universal. Terjemahan pertama dari kata "Policy" yaitu kebijakan dan terjemahan lainya adalah kebijaksanaan. Meskipun demikian, kecenderungannya adalah "Policy" diterjemahkan sebagai kebijakan sehingga dalam hal ini "Public Policy" dimaknai sebagai Kebijakan Publik (Moch. Iqbal, 2014).

Mengenai definisi kebijakan publik, terdapat beberapa ahli yang menyatakan pendapatnya. Thomas R. Dye menyatakan "Public Policy is whatever the government choose to do or not to do". (Kebijakan pemerintah adalah apapun pilihan pemerintah untuk melakukan sesuatu atau tidak melakukan sesuatu). James E. Anderson mendefinisikan kebijakan publik yaitu "Public Policies are those policies developed by govermental bodies and officials". (Kebijakan publik adalah kebijakan-kebijakan yang dikembangkan oleh badanbadan dan pejabat-pejabat pemerintah). Sementara itu, menurut David Aeston "Public Policy is the authoritative allocation of values for the whole society". (Kebijakan Publik adalah pengalokasian nilai-nilai secara syah kepada seluruh anggota masyarakat). Berdasarkan beberapa definisi yang disampaikan oleh beberapa ahli tersebut dapat disimpulkan bahwa kebijakan publik adalah tindakan-tindakan yang dibuat oleh pemerintah baik untuk melakukan atau tidak melakukan sesuatu dengan tujuan tertentu ditujukan untuk kepentingan masyarakat (Moch. Iqbal, 2014).

Kebijakan publik menurut James E. Anderson (2014) memiliki empat jenis. Pertama, substantive and procedural policies. Substantive policy adalah suatu kebijakan dilihat dari subtansi masalah yang dihadapi oleh pemerintah. Sementara, procedural policy adalah suatu kebijakan dilihat dari pihak-pihak yang terlibat dalam perumusannya (policy stakeholders). Kedua, distributive, redistributive, and regulatory policies. Distributive policy adalah suatu kebijakan yang mengatur tentang pemberian pelayanan/keuntungan kepada individu-individu, kelompokkelompok, atau perusahaanperusahaan. Redistributive policy adalah suatu kebijakan yang mengatur tentang pemindahan alokasi kekayaan, pemilikan atau hakhak. Regulatory policy adalah suatu kebijakan yang mengatur tentang 
pembatasan/pelarangan terhadap perbuatan/tindakan. Ketiga, material policy yaitu kebijakan yang mengatur tentang pengalokasian/penyediaan sumber-sumber material yang nyata bagi penerimanya. Keempat, public goods and privat goods policies. Public goods policy adalah suatu kebijakan yang mengatur tetang penyediaan barang-barang/pelayanan-pelayanan oleh pemerintah, untuk kepentingan orang banyak. Sementara itu, private goods policy adalah kebijakan yang mengatur tentang penyediaan barang-barang/pelayanan oleh pihak swasta untuk kepentingan individuindividu di pasar bebas, dengan imbalan biaya tertentu.

Berdasarkan jenis kebijakan publik yang disampaikan oleh James E. Anderson maka dapat dilihat bahwa potensi korupsi sangat tinggi terjadi pada jenis kebijakan publik yang keempat yaitu jenis public goods policy. Pada jenis kebijakan publik ini terjadi realisasi dari anggaran belanja pemerintah dan itu berarti terdapat aliran uang di dalamnya. Kondisi demikian menjadi rentan terhadap prilaku korup yang bermaksud untuk mencuri uang negara dengan memanfaatkan posisi dan jabatan yang melekat padanya. Secara logis dapat diterima bahwa salah satu episentrum korupsi adalah wilayah dimana terjadi perputaran uang. Hal ini sejalan dengan tabulasi data penanganan korupsi KPK berdasarkan jenis perkara tahun 2004 sampai pada tahun 2014 yang mencatat 126 kasus korupsi dalam proses pengadaan barang/jasa oleh pemerintah. Pada kasus ini, merujuk pendapat Romli bahwa sering kali terjadi perdebatan dikalangan ahli apakah perbuatan pejabat publik yang telah merugikan keuangan negara apakah diproses secara pidana atau melalui mekanisme administrasi.

Korupsi sebagai suatu kejahatan, mempunyai definisi yang beraneka ragam. Setiap definisi yang dikemukakan oleh para ahli itu tergantung dari perspektif bagaimana tindakan korupsi itu dilihat. Meskipun demikian, hampir semua ahli sepakat bahwa korupsi merupakan perbuatan yang buruk, bejat, yang pada intinya bertentangan dengan moral dan hukum yang berlaku pada masyarakat Indonesia bahkan dunia. Robert 0. Tilman $(\mathrm{H}$. Elwi Danil, 2014) menyatakan bahwa seperti halnya keindahan, pengertian korupsi yang sesungguhnya tergantung dari cara pandang dan dari sudut mana orang memandangnya. Penggunaan suatu perspektif tertentu akan menghasilkan pemahaman yang tidak sama tentang makna korupsi dengan penggunaan perspektif yang lain. Penggunaan pendekatan yuridis untuk memahami makna korupsi secara konseptual, akan menghasilkan suatu pengertian yang berbeda dengan penggunaan pendekatan-pendekatan lain seperti pendekatan sosiologis, kriminologis, dan politis.

Korupsi berdasarkan Black's Law Dictionary sebagaimana disusun oleh Hendry Campbell Black yaitu "an act done with an intent to give some adventage inconsistent with official duty and the rights of others". Termasuk pula dalam pengertian corruption menurut Black adalah perbuatan seorang pejabat yang secara melanggar hukum menggunakan jabatannya untuk mendapatkan sesuatu keuntungan yang berlawanan dengan 
kewajibannya. Sementara itu, Transparancy International (Marwan Mas, 2014) mendefinisikan korupsi sebagai "corruption involves behavior on the part of officials in the public sector, whether politicians or civil servants, in wich they improperly and unlawfully enrich themselves, or those close to them, by the public power entrusted them."

Korupsi menurut Leiken (Azyumardi Azra' 2002) adalah penggunanaan kekuasaan publik (public power) untuk mendapatkan keuntungan (material) pribadi atau kemanfaatan politik. Sejalan dengan apa yang dikemukakan Leiken adalah apa yang disampaikan oleh Myint. Myint Uournal Communication Spectrum, Vol. 3 No. 1, Februari-Juli 2013) menyebutkan korupsi sebagai penggunaan jabatan publik untuk keuntungan pribadi, atau dengan kata lain, penggunaan posisi resmi, pangkat atau status oleh pegawai kantor untuk kepentingan pribadinya.

Berdasarkan definisi yang telah dikemukakan oleh beberapa ahli tersebut, dengan menggunakan pendekatan dari siapa yang bertindak korup dapat dipahami bahwa pada dasarnya korupsi sangat dekat dengan mereka yang memiliki jabatan atau kekuasaan tertentu. Kekuasaan di sini merujuk pada kekuasaan publik dengan kewenangan sebagai penyelenggara pemerintahan dengan pengambilan kebijakan sebagai tugas, kewajiban dan wewenang yang melekat padanya. Kewenangan yang dimiliki oleh pejabat tersebut dimanfaatkan dalam wujud prilaku korup untuk menguntungkan diri sendiri atau orang lain yang dekat dengannya.

Lord Acton dalam artikel yang ditulis Eddy O.S. Hiariej menyatakan bahwa kekuasaan cenderung untuk korupsi. Lebih lanjut, Eddy mengatakan bahwa pendapat Lord Acton selaras dengan apa yang dikemukakan oleh Montesquieu bahwa terhadap orang yang berkuasa ada tiga kecenderungan. Pertama, kecenderungan untuk mempertahankan kekuasaan. Kedua, memperbesar kekuasaan. Ketiga, memanfaatkan kekuasaan. Dalam kaitannya dengan memanfaatkan kekuasaan inilah maka sering terjadi apa yang disebut abuse of power yang seringkali memperkaya diri sendiri atau orang lain (Eddy O.S. Hiariej, 2005). Sementara itu, Hakikat kekuasaan menurut Mochtar Kusumaatmadja adalah cenderung akan haus kekuasaan lagi tanpa batas. Soerjono Soekanto (1987) mengemukakan bahwa Secara luas gejala korupsi ditandai dengan adanya penggunaan kekuasaan dan wewenang publik untuk kepentingan pribadi atau golongan tertentu, yang sifatnya melanggar hukum dan norma-norma lainnya. Penekanannya di sini adalah pada penggunaan kekuasaan dan wewenang publik, oleh karena setiap pihak biasanya dibebani kewajiban untuk tidak menyalahgunakan hak secara sewenang-wenang. Korupsi menurut Romli Atmasasmita (2004) berkaitan pula dengan kekuasaan karena dengan kekuasaan itu penguasa dapat menyalahgunakan kekuasaannya untuk kepentingan pribadi, keluarga dan kroninya.

Mengenai sebab terjadinya korupsi kebijakan, menarik untuk mengikuti apa yang ditawarkan oleh Robert Klitgaard yang merumuskan dalam suatu formula. Korupsi (corruption) menurut Robert Klitgaard (Marwan Mas) sama 
dengan monopoli (monopoly) ditambah dengan kewenangan/kebijakan (discretion) dikurangi akuntabilitas (accountability). Secara singkat dapat dibentuk formula yaitu $\mathrm{C}=\mathrm{M}+\mathrm{D}-\mathrm{A}$. Artinya, tindakan korup sangat mungkin terjadi pada wilayah dimana berlangsungnya monopoli ditambah dengan kewenangan yang besar minus akuntabilitas. Lebih lanjut, dengan menggunakan logika ekuivalen seperti yang ditawarkan Klitgaard mengenai korupsi kebijakan, dapat diterima bahwa semakin besar kewenangan (discretion) yang dimiliki pejabat publik maka potensi korupsi akan semakin tinggi begitu juga sebaliknya. Teori ini bersifat universal, karena tidak membedakan apakah aktivitas tersebut berkaitan dengan sektor swasta atau publik.

Pendapat lain mengenai sebab terjadinya korupsi adalah apa yang dikemukakan oleh Jack Bologne. Faktor-faktor yang menyebabkan terjadinya korupsi menurut sebagai suatu kecurangan Bologne (Marwan Mas ) meliputi keserakahan (greeds), kesempatan (opportunities), kebutuhan (needs) dan pengungkapan (exposures). Greeds berkaitan dengan adanya perilaku serakah yang berpotensi ada di dalam diri setiap orang. Oleh karena itu, untuk mencegah agar keserakahan dapat dikendalikan, perlu meningkatkan pemahaman dan pelaksanaan nilai-nilai agama dan menumbuhkan nilai-nilai "budaya malu" melakukan korupsi secara nasional. Opportunities berkaiatan erat dengan kondisi organisasi (instansi pemerintah, swasta dan masyarakat) yang tidak profesional, sistem manajemen yang tidak transparan, kepemimpinan yang tidak dapat diteladani, serta mengabaikan pengawasan yang ketat, sehingga memberi kesempatan bagi seseorang untuk melakukan korupsi. Needs berkaiatan dengan faktorfaktor yang disebabkan oleh sifat konsumenrisme individu-individu dalam kehidupan modern. Untuk mencegah timbulnya perilaku tersebut, antara lain memenuhi kebutuhan dan kesejahteraan hidup individu yang ada dalam organisasi agar seimbang dengan kinerjanya. Exposures berkaitan dengan tindakan represif yang tidak konsisten sebagai konsekuensi yang harus diterima oleh pembuat korupsi. Untuk memastikan bahwa seseorang telah melakukan korupsi yang harus diberantas, dibutuhkan pranata hukum yang jelas dan tegas, serta pelaksanaannya yang konsisten tanpa dicampuri oleh kepentingan politis.

\section{Korupsi Kebijakan Sebagai White Collar Crime, Occupational Crime, dan Discretionary Corruption}

Korupsi kebijakan adalah jenis korupsi yang dilakukan oleh pelaku dengan jabatan wewenang tertentu. Artinya, melalui pendekatan siapa pelaku kejahatan terlihat bahwa mereka adalah orang dengan status sosial tinggi, dihormati dan tentunya memiliki kemampuan intelektual di atas orang pada umumnya. Oleh karena itu, kejahatan jenis ini disebut dengan istilah kejahatan kerah putih (white collar crime) yatu kejahatan yang dilakukan oleh orang-orang dalam lingkungan kerja menggunakan pakaean berkerah putih sebagai penggambaran bahwa mereka merupakan orang yang memiliki jabatan, terhormat dan dengan status sosial tinggi. 
Penggunaan istilah white collar crime ini adalah sebagai bentuk kontradiksi dari kejahatan yang dilakukan oleh orang biasa dengan sebutan kejahatan kerah biru (blue collar crime).

Istilah white collar crime mulai muncul pada pertengahan abad ke20. Meskipun demikian, sejarah kelahiran white collar crime dimulai oleh Edward A Ross (1806-1951) dan kemudian dipopulerkan oleh E.H. Sutherland (1883-1950) pada tahun 1949 dalam pidatonya dihadapan The American Sociological Society. Istilah ini kemudian diterjemahkan ke dalam beberapa bahasa antara lain disebut, "crime en col blanc" (Prancis), "criminalita in colleti bianchi" (Italia), "Weisse-Kragen Kriminalitat" (Jerman), dan disebut "El delito cuello blanco (Spanyol) (Romli Atmasasmita, 1995).

White collar crime secara historis berasal dan berkembang di negara barat (Amerika Serikat), dipopulerkan oleh pakar sosiologi negara tersebut serta bertitik tolak pada sosio-kultur masyarakat barat. Bentuk kejahatan ini kurang lebih muncul pada tahun 1939 di Amerika Serikat, semata-mata merupakan kejahatan yang hanya berkaitan dengan pola prilaku kalangan pengusaha dan politisi. Sutherland bahkan menegaskan bahwa white collar crime merupakan "the upperworld counterparts of the professional thieves". Betapa pentingnya white collar crime dalam pandangan Sutherland sehingga pada awal pidatonya dihadapan perkumpulan masyarakat sosiologi Amerika Serikat pada tahun 1939 ia menegaskan sebagai berikut: "the conventional explanations (of crime, pen.) are invalid principally because they are derived from biased samples. The sample are biased in that they have not included vast areas of criminal behavior of persons not in the lower class. One of these neglected area is the criminal behavior of business and professional men." Pengertian dasar dari konsep white collar crime yang dikemukakan oleh Sutherland (Muhammad Mustofa, 2010) adalah untuk menunjuk tipe pelaku dari suatu kejahatan (white collar criminal) yaitu " orang dari kelas sosial ekonomi tinggi yang melakukan pelanggaran-pelanggaran terhadap hukum yang dibuat untuk mengatur pekerjaannya." Terminologi yang digunakan oleh Sutherland adalah white collar criminal.

Objek kajian studi mengenai white collar crime mengalami perkembangan dari waktu ke waktu. Pada era tahun 1970-an menurut AIC Proceedings sebagaimana dikutip Van den Heuvel (Romli Atmasasmita) perhatian dan studi white collar crime mengalami pergeseran-pergeseran dan dominasi peran. Semula studi diarahkan kepada pelakunya (offenders), kemudian beralih kepada perbuatannya (offence), dari perbuatan kemudian berlalih kepada organisasi/perusahaannya. Studi white collar crime terakhir menitikberatkan pada akibatnya (consequences).

Hazel Croall (Baharuddin Lopa, 2002) dalam bukunya White Collar Crime merumuskan "White Collar Crime is defined as the abuse of a legitimate occupational rule which is regulated by law... the term white collar crime with fraud, embezzlement and other offences associated with high status employees." Apa yang disampaikan oleh Hazel Croall ini 
terlihat memberikan penekanan pada penyalahgunaan jabatan untuk mengartikan white collar crime. Jabatan di sini adalah jabatan yang legitimate diatur oleh hukum. Pengertian lebih luas mengenai white collar crime adalah apa yang disampaikan oleh Biderman dan Reiss yang juga menambahkan unsur kepercayaan dari pelakunya. Biderman dan Reiss (Munir Fuady, 2004) mengartikan white collar crime sebagai setiap pelanggaran hukum dengan ancaman hukuman, dengan menggungkan kedudukan yang penting, kekuasaan, dan kepercayaan dari pelakunya, dalam suatu ketertiban institusi politik dan ekonomi yang legitimate, dengan tujuan untuk mendapatkan keuntungan yang tidak legal, atau untuk dapat melakukan perbuatan tidak legal untuk kepentingan pribadi atau organisasi tertentu. Sementara itu, dengan subtsansi yang tidak jauh berbeda Coleman mendifinisikan white collar crime sebagai suatu pelanggaran hukum yang dilakukan oleh orang atau kelompok orang dalam menjalankan tugasnya yang tergolong dihormati orang atau dalam melaksanakan jabatan yang legitimate, atau dalam kegiatan bisnis.

Kharakteristik white collar crime yang membedakannya dengan kejahatan-kejahatan lain adalah terletak pada kepribadian pelakunya. Schneider (Romli Atmasasmita) telah menetapkan enam karakteristik pelaku kejahatan di bidang ekonomi dengan sendirinya dapat dipandang sebagai karakteristik pelaku white collar crime, sebagai berikut:

a. He is "stigmatized".

b. He commits his offences in connection with his occupation. c. He does not develop a "criminal self-image"; he does not perceive himself as a criminal.

d. He justifies their crimes with the open or silent support of the public opinion.

e. He is motivated by rational thinking, not emotion.

f. He generally well adjuted, social conforming life and he is well respected by the people in his social community.

Karakteristik white collar crime secara langsung akan mempengaruhi setiap tindakan dari pelakunya. Dalam kaitannya dengan penegakan hukum misalnya, pelaku merasa bahwa hukum tidak dapat menyentuh perbuatan yang dilakukan. Pelaku dengan sadar menggunakan jabatan dan kemampuan untuk merekayasa kebijakan termasuk juga menempatkan kepentingan pribadi di tengah-tengan kepentingan masyarakat luas. Menjadi benar apa yang disampaikan oleh Ruth S. Cavan(Gerson W. Bawengan, 1977) bahwa kaum white collar crime sering menganggap dirinya melebihi atau kebal terhadap hukum. Hal tersebut disebabkan oleh kekuasaan dan kemampuan materiil yang mereka miliki. Sementara, prinsip para koruptor menurut Romli bahwa korupsi merupakan "low risk and high profit activity" (Romli Atmasasmita).

Modal kekuasaan minus transparansi serta gerakan yang terstruktur melibatkan banyak pelaku mengakibatkan skandal white collar crime sulit untuk dideteksi. Dewasa ini, white collar crime menampakkan diri sebagai kejahatan terorganisir dengan modus operandi yang semakin canggih. Bagaimana tidak, dalam suatu skandal misalnya, white collar crime melibatkan pihak 
dari jajaran bawah sampai pada pucuk pimpinan tertinggi dalam suatu institusi. Hazel Croall (Baharuddin Lopa) menyatakan "inability of victims to detect offence is of course the mayor reason why so much white collar crime is unreported." Skandal-skandal white collar crime tidak mudah dilacak. Adanya ketidakmampuan mengetahui secara dini terjadinya penyimpangan yang justru dilakukan secara tertutup oleh pejabat-pejabat penting yang berwenang mengambil keputusan di lingkungan bank yang bersangkutan. Selain itu, disebabkan juga terjadinya persekongkolan di antara sesama oknum pejabat di lingkungan perusahan itu, tanpa atau bekerjasama dengan pihak luar, sehingga mereka sedapat-dapatnya untuk menutup-nutupi skandal yang terjadi.

Upaya untuk menanggulangi white collar crime sejak lama telah menyita banyak tenaga, waktu dan biaya dari pihak kepolisian maupun aparatur penegak hukum lain, baik di negara-negara maju maupun di negara-negara berkembang. Kesulitan-kesulitan penanggulangan white collar crime secara gamblang dikemukakan oleh Van den Heuvel (Romli Atmasasmita) dalam seminar Internasional "International Trends in Crimes: East Meets West" di Bali, sebagai berikut:

Since Sutherland" studies of $1938, \ldots$ it is difficult to control corporite crimes by criminalization. Dozens of studies from many countries document the reluctance to invoke formal procedures against corporate offender (Comer 1977; Levi 1981; Clarke 1990). There are problems with the responsible body; problems with this investigating agency and/or the public prosecutions; incompetence; lack of money and time; and sometimes a lack of will and belief; problems with the construction of evidence; malicious intention or not, problems with the trial; problems with the sentence-whether imprisonment or fine, who and how much, and what are the likely side effect on the well being of the company and it's workers.

Penegakan hukum terhadap white collar crime seringkali mengalami kendala pada tataran penyidikan, penuntutan, pembuktian termasuk di dalammnya adalah persoalan pada tataran pengadilan. Dengan kekuasaan yang dimiliki, pelaku melakukan intervensi pada setiap proses dan level dalam penegakan hukum. Hal ini menjadikan proses hukum tidak adil, parsial kepada mereka yang berkuasa dengan status sosial kapital tinggi. Hukum menampakkan diri dalam bentuk rekayasa, terlihat baik di permukaan sementara di dalam penuh dengan ketidakjujuran dan simulakra.

"Drakula tanpa taring", menjadi julukan yang tepat untuk menggambarkan para pelaku white collar crime. Ganas dan kejam tetapi kelihatannya sopan dan berwibawa. Para pelaku white collar crime biasanya terdiri dari orang-orang terhormat atau orang-orang mempunyai kekuasaan/uang, yang biasanya menampakkan dirinya sebagai orang yang baik-baik bahkan banyak di antara mereka yang dikenal sebagai dermawan, yang terdiri dari politikus, birokrat pemerintah, direktur perusahaan besar, bankir, penasehat investasi, broker saham, kontraktor, produsen 
barang tertentu, sindikasi mafia, dan tentu juga lawyer dan para penegak hukum, serta masih banyak lagi, para pelaku perbuatan white collar crime ini sering disebut dengan istilahistilah yaitu white collar criminals, criminaloids, criminals of the upper world dan educated criminal (Munir Fuady).

Dalam perkembanggannya lahir dua konsep yang merupakan turunan dari white collar crime yaitu occupational crime dan corporate crime. Dari dua kategori dasar white collar criminality tersebut berkembang menjadi kategorikategori yang lebih kompleks (Muhammad Mustofa). Green (Muhammad Mustofa) mengkatagorisasikan pola umum yang seragam dari kejahatan whitecollar menjadi empat. Pertama, kejahatan untuk kepentingan organisasi/majikan (organizational occupational crime). Kedua, kejahatan oleh pejabat dalam melaksanakan otoritas birokrasi pemerintahan (state authority occupational crime). Ketiga, kejahatan oleh profesional dalam rangka melakukan pekerjaan profesionalnya (professional occupational crime). Keempat, Kejahatan oleh individu dalam rangka pekerjaan individual tersebut (individual occupational crime). Sementara itu, Jo Ann Miller membuat katagori sebagai berikut:

a. Organizational occupational crime.

b. Government occupational crime.

c. Professional occupational crime.

d. Individual occupational crime.

Korupsi kebijakan publik termasuk occupational crime sebagai turunan dari white collar crime. Occupational crime merupakan bagian dari white collar crime yaitu kejahatan yang dilakukan oleh seseorang yang menduduki jabatan terhormat dan kejahatan tersebut terkait dengan jabatan pekerjaannya yang sah (Muhammad Mustofa). Occupational crime adalah white collar crime dengan pelaku secara spesifik yaitu orang-orang yang duduk pada jabatan tertentu. Jabatan mempunyai peran yang penting dalam kejahatan jenis ini, karena atas dasar jabatan, pelaku memiliki wewenang yang legitimate menurut hukum dan melegalkan bentuk perbuatan pelaku dalam bentuk pengambilan kebijakan.

Green (Muhammad Mustofa) dalam membahas occupational crime menguraikan adanya dua unsur dari kejahatan jabatan tersebut. Pertama, suatu tindakan yang dapat dikenai hukuman berdasarkan hukum. Kedua, tindakan yang dilakukan melalui kesempatan yang ada dalam peran jabatan yang sah. Tindakantindakan yang dapat dikenai hukuman tersebut berupa hukuman yang diberikan oleh negra meliputi denda, hukuman penjara, perintah pembatasan tertentu (injuction), pencabutan izin perintah, perintah penghentian (desist order).

Occupational crime memiliki jenis yang spesifik yang dimaksud dengan occupational crime birokrasi. Occupational crime birokrasi adalah occupational crime yang dilakukan oleh aparat birokrasi pemerintahan yang tugas utamanya melayani anggota-anggota masyarakat. occupational crime birokrasi ini lebih dikenal dengan sebutan korupsi. Korupsi dalam kaitan ini dapat dijelaskan sebagai tindakan penyalahgunaan wewenang yang dilakukan oleh aparat birokrasi dengan tujuan untuk memperoleh keuntungan ekonomi bagi dirinya 
pribadi. Penyalahgunaan wewenang tersebut terkait dengan kedudukannya sebagai aparat birokrasi yang diberi kewenangan untuk memberikan pelayanan publik sesuai dengan ketentuan hukum yang berlaku (Muhammad Mustofa).

Terdapat beberapa pakar yang mencoba merumuskan pengertian korupsi yang ditujukun pada occupational crime birokrasi. Key (Muhammad Mustofa ) merumuskan korupsi sebagai "penyalahgunaan pengendalian kekuasaan dan sumber daya pemerintahan untuk kepentingan keuntungan pribadi atau partai,... dan tidak harus berbentuk uang". Costikyan (Muhammad Mustofa) sebagaimana dirujuk Gardiner dan Olson mendefinisikan korupsi yaitu "menggunakan kekuasaan pemerintahan untuk tujuan bukan untuk kepentingan pemerintah". Masih dalam rujukan Gardiner dan Olson, Wilson (Muhammad Mustofa ) merumuskan korupsi dengan menyatakan "korupsi terjadi apabila sesorang, sebagai imbalan bagi suatu keuntungan pribadi, melakukan tindakan di luar kewajibannya".

Berdasarkan

beberapa pengertian yang diutarakan oleh para pakar tersebut terdapat beberapa poin penting yang menjadi catatan terhadap occupational crime birokrasi. Pertama, dilihat dari pelakunya adalah seseorang yang duduk pada birokrasi atau jabatan publik yang mempunyai wewenang tertentu melekat pada jabatannya yang legitimate berdasarkan hukum yang berlaku. Kedua, terjadi penyalahgunaan kewenangan dalam menjalankan tugas dan kewajiban sebagai pejabat publik dengan maksud menguntungkan diri pribadi atau yang dekat dengan pelaku. Ketiga, merugikan kepentingan masyarakat tidak hanya dalam bentuk uang tetapi juga yang lainnya.

Korupsi kebijakan dalam pemetaan Benveniste termasuk jenis discretionary corruption. Korupsi menurut Benveniste (Mansyur Semma, 2008) dapat dipetakan menjadi empat jenis. Pertama, discretionary corruption yaitu korupsi yang dilakukan karena adanya kebebasan dalam menentukan kebijakan, sekalipun tampaknya bersifat sah, bukanlah praktik-praktik yang dapat diterima oleh para anggota organisasi. Kedua, illegal corruption yaitu suatu jenis tindakan yang membongkar atau mengacaukan bahasa ataupun maksud-maksud hukum, peraturan dan regulasi tertentu. Efektifitas untuk jenis korupsi ini bisa diukur. Namun, ia jauh lebih mudah untuk dikendalikan. Ketiga, mercenery corruption yaitu jenis korupsi dengan maksud untuk memperoleh keuntungan individual/pribadi. Biasanya korupsi jenis ini banyak digunakan oleh para kompetitor politik dalam suksesi ataupun kampanye politik. Keempat, ideological corruption yaitu korupsi yang dilakukan lebih karena kepentingan kelompok, karena komitmen ideologis seseorang yang mulai tertanam di atas nama kelompok tertentu. Biasanya korupsi jenis ini amat sulit untuk dideteksi atau diketahui landasannya secara material. Seseorang yang telah didoktrin pada sebuah pandangan lebih rela mati atas nama simbol atau tanda tertentu di dalam kelompok yang dinilai sakral, dibanding seseorang itu harus lari bila berhadapan dengan bahaya yang mengancam jiwanySimpulan 
Korupsi kebijakan oleh pejabat publik lahir menjadi korupsi jenis baru yang banyak menyita perhatian publik. Korupsi jenis ini menjadi suatu fenomena yang berkembang pada masyarakat Indonesia. Kasuskasus yang melibatkan Siti Fadilah Supari, Hadi Poenomo dan Budi Mulya adalah beberapa kasus yang menjadi bukti verifikatif bahwa fenomena korupsi kebijakan nyata dalam praktek kenegaraan di Indonesia. Korupsi kebijakan dalam perspektif kriminologi termasuk kualifikasi white collar crime dengan turunannya yaitu occupational crime dan discretionary crime. Korupsi kebijakan lahir karena adanya jabatan tertentu dengan wewenang yang legitimate berdasarkan hukum tapi terdapat kepentingan pribadi di tengah kepentingan masyarakat sebagai nilai jahat untuk mencuri uang negara. Pada titik ini terlihat bagaimana hubungan kekuasan dengan praktek korupsi yang memiliki kecenderungan semakin besar kekuasaan maka potensi korupsi akan semakit tinggi.

\section{Saran}

Dengan mengetahui bagaimana hubungan antara kekuasaan dengan perilaku korup, maka dalam rangka pemberantasan korupsi perlu untuk memberikan perhatian lebih pada wilayah-wilayah dimana terdapat kekuasaan dengan kewenangan yang besar. Konsentrasi pemberantasan korupsi hendaknya diarahkan pada salah satu episentrum korupsi yaitu wilayah dimana titik kekuasaan bekerja. Sistem pengawasan yang terintegrasi bersifat holistik melibatkan semua pihak adalah salah satu faktor pengurang kemungkinan praktek korupsi yang berlarut-larut di Indonesia. Hal ini tentunya harus didukung oleh seperangkat peraturan sebagai payung hukum yang membuat jelas setiap aturan main dalam praktek kenegaraan.

\section{Daftar Pustaka}

\section{Buku}

Atmasasmita, Romli, 2013, Buku 2 Kapita Selekta Kejahatan Bisnis Dan Hukum Pidana, Fikahati Aneska, Jakarta.

Atmasasmita, Romli, 1995, Kapita Selekta Hukum Piadana Dan Kriminologi, Mandar Maju, Bandung.

Atmasasmita, Romli, 2004, Sekitar Masalah Korupsi: Aspek Nasional Dan Aspek Internasional, Mandar Maju, Bandung.

Bawengan, Gerson W., 1977, Pengantar Psychology Kriminil, Pradnya Paramita, Jakarta.

Bonger, 1982, Pengantar Tentang Kriminologi, PT. Pembangunan (terjemahan oleh Koesnoen), Jakarta.

Danil, H. Elwi, 2014, Korupsi: Konsep, Tindak Pidana, dan Pemberantasannya, Rajawali Pers, Jakarta.

Fuady, Munir, 2004, Bisnis Kotor: Anatomi Kejahatan Kerah Putih, Citra Aditya Bakti, Bandung.

Hurwitz, Stephan, 1986, Kriminology (disadur oleh L. Moeljatno), Bina Aksara, Jakarta.

Lopa, Baharuddin, 2002, Kejahatan Korupsi Dan Penegakan Hukum, Kompas, Jakarta.

Mas, Marwan, 2014, Pemberantasan Tindak Pidana Korupsi, Ghalia Indonesia, Bogor. 
Mustofa, Muhammad, 2010, Kleptokrasi: Persekongkolan Birokrat-Korporat Sebagai Pola White Collar Crime di Indonesia, Kencana, Jakarta.

Semma, Mansyur, 2008, Negara Dan Korupsi: Pemikiran Mochtar Lubis Atas Negara, Manusia Indonesia, Dan Perilaku Politik, Yayasan Obor Indonesia, Jakarta.

Soekanto, Soerjono dan Abdullah, Mustafa, 1987, Sosiologi Hukum Dalam Masyarakat, Rajawali, Jakarta.

Syarif, Laode M. dan Didik Purwoleksono, E., Hukum Anti Korupsi, Kemitraan.

\section{Jurnal}

Azyumardi Azra, "Korupsi Dalam Perspektif Good Governance", Jurnal Kriminologi Indonesia, Vol. 2 No. 1, Januari 2002.

Bambang Sukma Wijaya, "Korupsi Komunikasi Dalam Dimensi Pesan, Media, Konteks Dan Perilaku: Sebuah Proposisi Teoretis Untuk Riset", Journal Communication Spectrum, Vol. 3 No. 1, Februari-Juli 2013.

Eddy O.S. Hiariej, 2005, Membasmi Korupsi, Mimbar Hukum Edisi No. 51/X/2005, Universitas Gadjah Mada, Yogyakarta.

Moch. Iqbal (Koordinator Peneliti), "Kriminalisasi Kebijakan Pejabat Publik", Laporan Penelitian, Puslitbang Hukum Dan Peradilan Badan Litbang Diklat Kumdil Mahkamah Agung RI, 2014.

\section{Artikel Koran}

\begin{abstract}
"KPK Sadap Pejabat Yang Niat Korupsi”, Bali Post, Rabu 26 Agustus 2015.

"Soal SE Kesalahan Administrasi: Kebijakan Mengandung Pidana Tetap Diproses", Bali Post, Minggu 6 September 2015.

W. Riawan Tjandra, "Inovasi, Diskresi, dan Korupsi", Kompas, Selasa 22 September 2015.
\end{abstract}

\section{Artikel Internet}

"Pejabat Korup Tetap Tak Aman: KPK Tidak Keberatan Pemerintah Terbitkan Rancangan PP Sanksi Administrasi”, Kompas, Senin 14 September 2015

ACCH, "Penangan TPK Berdasarkan Jenis Perkara", http://acch.kpk.go.id/berdasarkanjenis-perkara, diakses pada 12 Mei 2015.

ACCH, "Rekapitulasi Penindakan Pidana Korupsi", http://acch.kpk.go.id/rekapitulasipenindakan, diakses pada 12 Mei 2015.

Adrianus Mandey, Taufik Rahadian, "Korupsi BCA Terkait Kebijakan, KPK Siap Beri Alat Bukti", viva.co.id, http://nasional.news.viva.co. id/news/read/618349korupsi-bca-terkaitkebijakan--kpk-siap-berialat-bukti, diakses pada 30 September 2015.

Editor, "Konsentrasi Korupsi Mengarah Pada Kebijakan Publik", Hukum Online.com, http://www.hukumonline.co m/berita/baca/hol3142/kon sentrasi-korupsi-mengarahpada-kebijakan-publik, 
diakses pada 30 September 2015.

SBD, "Dilema Diskresi Di Tengah Godaan Korupsi”, Media Indonesia (Senin, 16 Juli 2012), http://ditjenmiltun.m ahkamahagung.go.id/index.p hp?option=com_content\&vie w=article\&id=1553: dilemadiskresi-ditengah-godaan- korupsi\&catid=114:umum, diakses pada 30 September 2015.

Transparancy International The Global Coalition Against Corruption, "Corruption Perception Index 2014", http://www.transparency.or g/cpi2014/results, diakses pada 12 Mei 2015. 